\section{Histoire évolutive du complexe Afzelia Smith (Leguminosae - Caesalpinioideae) dans les écosystèmes forestiers et savanicoles d'Afrique tropicale}

\section{Segbedji Armel Loïc DonKPEgan} RÉSUMÉ

Le genre Afzelia Smith est connu pour comporter sept espèces africaines d'arbres dont deux se retrouvent dans la région zambézienne, une en région soudanienne et les quatre autres en région guinéo-congolaise. Ces taxons, à haute valeur commerciale, sont difficiles à distinguer les uns des autres. Ils sont donc commercialisés sous un même nom : « doussié » ou " afzelia ». Ces difficultés de distinction peuvent s'avérer préjudiciables à la gestion durable des populations.

Le but de cette thèse de doctorat est de caractériser l'histoire évolutive du genre Afzelia. Plus spécifiquement, cette étude vise à : (i) évaluer le niveau des divergences morphologiques au sein du genre et décrire les relations phylogénétiques, afin de quantifier l'isolement reproductif entre les taxons d'Afzelia en mettant en évidence le rôle des changements climatiques passés et/ou des gradients écologiques dans la spéciation ; (ii) procéder à une analyse approfondie de la diversité et de la structuration génétique spatiale d'Afzelia spp.; (iii) identifier et décrire les facteurs écologiques, biotiques et abiotiques susceptibles d'influencer les flux géniques à l'échelle des populations d'une espèce d'Afzelia (A. bipindensis).

Une analyse morphogénétique des espèces a été effectuée et a confirmé la forte ressemblance botanique entre les taxons. Les espèces de savane se sont avérées être diploïdes et présentent la moitié de la taille du génome des espèces forestières qui sont donc tétraploïdes. Les phylogénies de gènes, nucléaires et chloroplastiques, diffèrent entre elles. De telles différences peuvent être générées à la suite d'épisodes d'hybridation ancestrale entre espèces. Ces hybridations seraient probablement anciennes et seraient survenues entre les lignées des espèces forestières et celles d'A. quanzensis (une espèce des savanes zambéziennes). La polyploïdie serait survenue entre 7 et 9,4 millions d'années au cours de l'histoire évolutive du genre. De plus, une assignation bayésienne et des analyses d'isolement reproductif ont suggéré l'existence de croisements interspécifiques, mais uniquement chez les espèces forestières distribuées en sympatrie. À une échelle spatiale plus limitée, deux groupes génétiques bien différenciés ont été observés en sympatrie chez $A$. bipindensis. Ceux-ci présentent une différenciation morphologique et un décalage phénologique de la floraison qui peut contribuer à leur isolement reproductif.

Cette étude a permis de mettre en évidence quelques points importants que sont : la découverte d'un complexe polyploïde au sein du genre Afzelia ; la confirmation de la délimitation des espèces diploïdes de savane ; et la nécessité de réviser la taxonomie des espèces tétraploïdes forestières.
Mots-clés : Afzelia spp., phylogénie, phylogéographie, structure et diversité génétique, polyploïdie, flux de gènes, phénologie, savane, forêts tropicales, Afrique tropicale.

\section{Evolutionary history of the Afzelia Smith (Leguminosae - Caesalpinioideae) complex in forest and savannah ecosystems of tropical Africa}

\section{ABSTRACT}

The genus Afzelia Smith includes seven African tree species: two are found in the Zambez region, one in the Sudanian region and four in the Guinea-Congo region. These taxa are commercially valuable but because they are difficult to distinguish, they are marketed under the same commercial name, either "doussié" or "afzelia", which complicates sustainable management of their populations.

The aim of this PhD thesis is to characterize the evolutionary history of the Afzelia genus. More specifically, our study aims to: (i) assess the extent of morphological divergence within the Afzelia genus and describe the phylogenetic relationships in order to quantify the reproductive isolation of the different taxa by identifying the role of past climate change and / or ecological gradients in the speciation of the genus; (ii) analyze the spatial genetic diversity and struc ture of Afzelia spp.; (iii) identify and describe the ecological, biotic and abiotic factors that may influence population-level gene flows in an Afzelia species (A. bipindensis).

Our morpho-genetic analysis of the different species confirmed the strong botanical resemblance between the taxa. The savannah species are diploid and their genome is half the size of the forest species, which are tetraploid. The phylogenies of the genes, nuclear and chloroplastic, are not the same. The differences observed could have been generated by ancient hybridization between species, which would have occurred between the forest lineages and those of $A$. quanzensis, a Zambezi savannah species. Polyploidy probably emerged during the evolutionary history of the genus between 7 and 9.4 million years ago. Bayesian assignment and reproductive isolation analyses also suggested interspecies crossing, but only among forest species distributed sympatrically. On a more limited spatial scale, two well differentiated genetic groups of $A$. bipindensis were observed to be sympatric. These show differences in their morphology and flowering phenology that could contribute to their reproductive isolation.

This study made several important findings: discovery of a polyploid complex within the Afzelia genus, confirmation of the boundaries of diploid savannah species and the need to revise the taxonomy of tetraploid forest species.

Keywords: Afzelia spp., phylogeny, phylogeography, genetic diversity, polyploidy, gene flow, phenology, savannah, tropical forests, tropical Africa.
Historia evolutiva del complejo Afzelia Smith

(Leguminosae - Caesalpinioideae) en ecosistemas forestales y de sabana de África tropical

\section{RESUMEN}

El género Afzelia Smith comprende siete especies africanas de árboles que se distribuyen del siguiente modo: dos en la región zambeziana, una en la sudanesa y cuatro en la región guineano-congoleña. Estos taxones, de gran valor comercial, se confunden fácilmente unos con otros y, por ello, se comercializan con el mismo nombre: "doussié" o "afzelia". Esta dificultad de identificación podría perjudicar el manejo sostenible de las poblaciones.

El objetivo de esta tesis doctoral es caracterizar la historia evolutiva del género Afzelia. En concreto, este estudio tiene como objeto: a) evaluar el nivel de divergencias morfológicas dentro de este género y describir las relaciones filogenéticas para cuantificar el aislamiento reproductivo entre taxones de Afzelia, poniendo de manifiesto el papel de los cambios climáticos pasados y/o de los gradientes ecológicos en la especiación; b) realizar un detallado análisis de la diversidad y estructuración genética espacial de Afzelia spp.; c) identificar y describir los factores ecológicos, bióticos y abióticos que pueden influir en los flujos génicos a nivel de la población de una especie de Afzelia (A. bipindensis).

Se efectuó un análisis morfogenético de las especies que confirmó la gran proximidad botánica entre los taxones. Las especies de sabana han resultado ser diploides y con la mitad del tamaño del genoma de las especies forestales que son, por tanto, tetraploides. Las filogenias de los genes nucleares y cloroplásticos difieren entre sí. Dichas diferencias pueden haber sido generadas por episodios de hibridación ancestral entre especies. Estas hibridaciones son probablemente antiguas y habrían surgido entre linajes de especies forestales $y$ de $A$. quanzensis (especie de la sabana zambeziana). La poliploidia habría aparecido entre los 7 y 9,4 millones de años de la historia evolutiva del género. Además, una asignación bayesiana y análisis de aislamiento reproductivo sugirieron la existencia de cruzamientos interespecíficos, pero sólo en las especies forestales distribuidas simpátricamente. A escala espacial más limitada, se observaron dos grupos genéticos bien diferenciados de $A$. bipindensis en simpatría. Estos presentan una diferenciación morfológica y un desfase fenológico de la floración que puede contribuir a su aislamiento reproductivo.

Este estudio puso de manifiesto algunos puntos importantes como: el descubrimiento de un complejo poliploide en el género Afzelia, la confirmación de la delimitación de las especies diploides de las sabanas y la necesidad de revisar la taxonomía de las especies tetraploides forestales.

Palabras clave: Afzelia spp., filogenia, filogeografía, estructura y diversidad genética, poliploidia, flujo de genes, fenología, sabana, bosques tropicales, África tropical. 


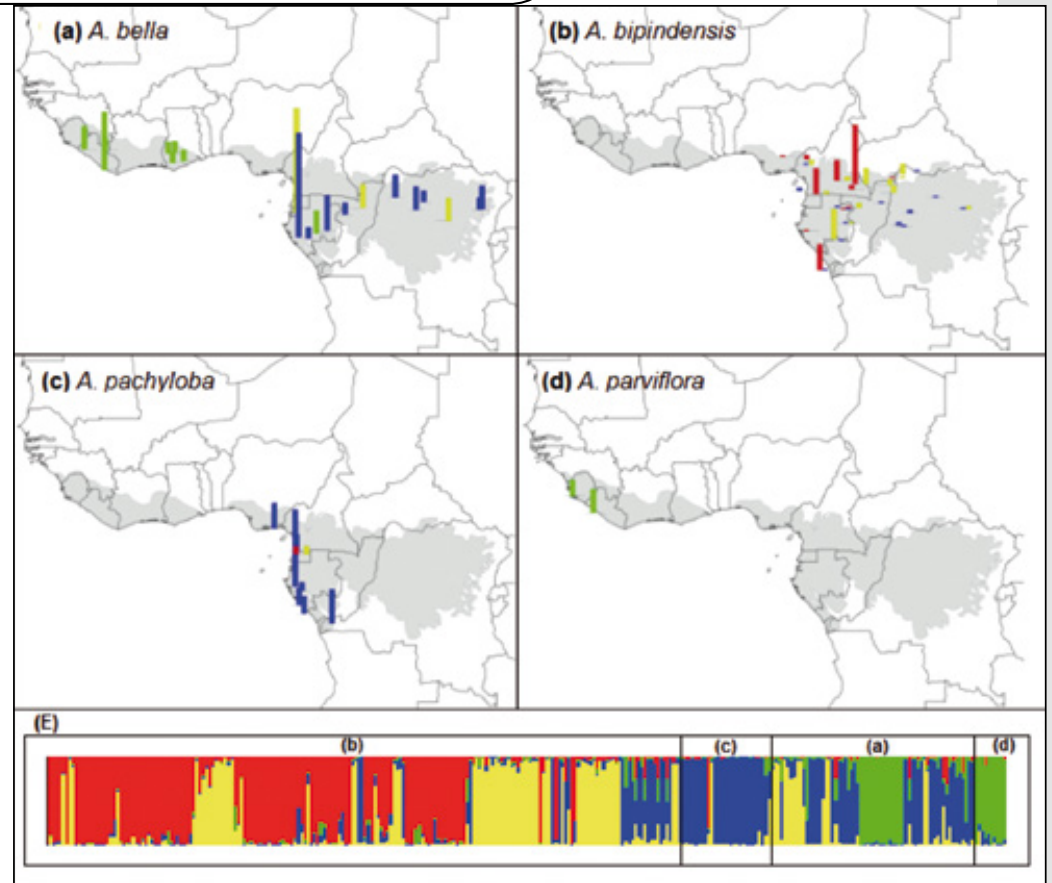

Figure 1.

Mélange génétique entre les quatre espèces d'Afzelia des forêts tropicales humides en Afrique. Structures agrégatives en grappes génétiques ( $\mathrm{E}$ ) détectées dans A. bella (a), A. bipindensis (b), A. pachyloba (c) et $A$. parviflora (d) en utilisant l'algorithme de classification bayésien implémenté dans STRUCTURE (K $=4)$. Les quatre structures agrégatives en grappes génétiques sont présentées sous forme d'histogrammes (avec le pourcentage individuel). Couleur rouge : classe génétique (GC) 1 ; jaune : $G C 4$; bleu : GC3 ; vert : GC2

Genetic admixture among the four Afzelia rain-forest species in Africa. Genetic clusters (E) detected in $A$. bella (a), A. bipindensis (b), A. pachyloba (c) and $A$. parviflora (d) using the Bayesian clustering algorithm implemented in STRUCTURE $(K=4)$. The four genetic clusters are presented as histograms (with individual percentages). Red: Genetic Cluster (GC) 1; yellow: GC4; blue: GC3; green: GC2.

Mezcla genética entre las cuatro especies de Afzelia de las selvas tropicales húmedas en África. Estructuras de agregación en grupos genéticos $(\mathrm{E})$ detectadas en A. bella (a), A. bipindensis (b), A. pachyloba (c) y A. parviflora (d) utilizando el algoritmo de clasificación bayesiano implementado en STRUCTURE $(K=4)$. Las cuatro estructuras de agregación en grupos genéticos se presentan como histogramas (con el porcentaje individual). Color rojo: clase genética (GC) 1; amarillo: GC4; azul: GC3; verde: GC2.

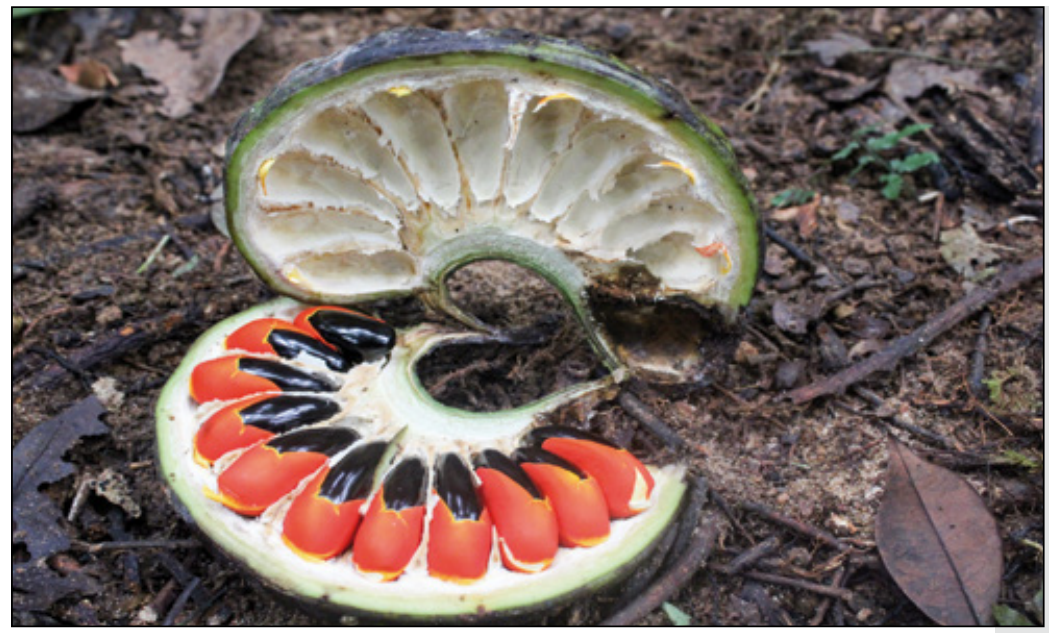

Photo 1.

Gousse et graines d'Afzelia bipindensis récoltées à Mayumba au Gabon. Fruit en gousse de 8 à $20 \mathrm{~cm}$ de long et 5 à $8 \mathrm{~cm}$ d'épaisseur, contenant une douzaine de graines de 2 à $5 \mathrm{~cm}$ de long. A. bipindensis est un arbre de $40 \mathrm{~m}$ de hauteur avec un tronc cylindrique sans branche de $25 \mathrm{~m}$ de long. Cette espèce produit un bois très stable, durable et dense (800 à $950 \mathrm{~kg} /$ $\mathrm{m}^{3}$ à $12 \%$ d'humidité), peu sensible à l'humidité avec un faible retrait et une bonne résistance aux xylophages et champignons.

Pod and seeds of Afzelia bipindensis harvested in Mayumba in Gabon. Fruit in pods 8 to $20 \mathrm{~cm}$ in length and 5 to $8 \mathrm{~cm}$ thick, each containing a dozen seeds 2 to $5 \mathrm{~cm}$ in length. A. bipindensis is a tree growing to $40 \mathrm{~m}$ in height with a cylindrical trunk $25 \mathrm{~m}$ in length before branching. The species produces a very stable, durable and dense wood $\left(800\right.$ to $950 \mathrm{~kg} / \mathrm{m}^{3}$ at $12 \%$ humidity), with low sensitivity to moisture, low shrinkage and good resistance to wood borers and fungi.

Vainas y semillas de Afzelia bipindensis cosechadas en Mayumba (Gabón). Fruto en vaina de 8 a $20 \mathrm{~cm}$ de largo y de 5 a $8 \mathrm{~cm}$ de grosor, que contiene una docena de semillas de 2 a $5 \mathrm{~cm}$ de largo. A. bipindensis es un árbol de $40 \mathrm{~m}$ de altura con un tronco cilíndrico sin ramas de $25 \mathrm{~m}$ de largo. Esta especie produce una madera muy estable, resistente y densa ( 800 a $950 \mathrm{~kg} / \mathrm{m}^{3}$ al $12 \%$ de humedad), poco sensible a la humedad, con baja contracción y una buena resistencia a xilófagos y hongos.

Bio Tech - Université de Liège, Belgique),

Docteur O. HARDY (Copromoteur, Université Libre de Bruxelles, Belgique).

Composition du jury

Président : Professeur P. Lejeune, Président du Département BIOSE.

Membres : Professeur G. MAHY (Gembloux Agro-Bio Tech - Université de Liège, Belgique), Docteur A. FAYOLLE (Gembloux Agro-Bio Tech - Université de Liège, Belgique), Docteur M. HeuerTz (INRA, France), Docteur J. DegreEF (Jardin Botanique de Meise, Belgique).

Langue de rédaction : français et anglais.

Accès au manuscrit : orbi.ulg.ac.be/bitstream/2268/212437/1/Donkpegan thesis 2017.pdf

\section{Contact :}

Cirad, Bios, UMR AGAP, TA A-108, 3, avenue Agropolis, 34398 Montpellier Cedex 5, France.

Gembloux Agro-Bio Tech - Université de Liège, Passage des Déportés, 2, 5030 Gembloux, Belgique. armel.donkpegan@cirad.fr 